\title{
The Determinant of Indonesian Stock Returns' Volatility: Evidence from Islamic and Conventional Stock Market
}

\author{
Septiana Indarwati ${ }^{a}$, Agus Widarjono ${ }^{{ }^{*}}$ \\ ${ }^{a}$ Faculty of Business and Economics, Universitas Islam Indonesia, Indonesia \\ *Corresponding email: agus.widarjono@uii.ac.id \\ doi http://dx.doi.org/10.22515/shirkah.v6i3.431
}

\begin{tabular}{|c|c|}
\hline ARTICLE INFO & ABSTRACT \\
\hline $\begin{array}{l}\text { Keywords: } \\
\text { Conventional Stock Price; } \\
\text { Islamic Stock Price; } \\
\text { Macroeconomic Variable; } \\
\text { Stock Return; Volatility } \\
\text { Article history: } \\
\text { Received: } 18 \text { July } 2021 \\
\text { Revised: } 09 \text { November } 2021 \\
\text { Accepted: } 12 \text { November } 2021 \\
\text { Available online: } 31 \text { December } \\
2021 \\
\text { To cite in APA style: } \\
\text { Indarwati, S., Widarjono, A. } \\
\text { (2021). The Determinant of } \\
\text { Indonesian Stock Retunrs' } \\
\text { Volatility: Evidence from } \\
\text { Islamic and Conventional } \\
\text { Stock Market. Shirkah: Journal } \\
\text { of Economics and Business, 6(3), } \\
\text { 277-296. }\end{array}$ & $\begin{array}{l}\text { Islamic stock market is apparently different from the } \\
\text { conventional stock market due to the prohibition of unlawful } \\
\text { goods and excessive risk-taking behavior. This study } \\
\text { explores the extent to which the Indonesian Islamic and } \\
\text { conventional stock returns' volatility responds to the } \\
\text { macroeconomic indicators. This study employs Jakarta } \\
\text { Islamic Index (JII) and Indonesian Stock Exchange (IDX) and } \\
\text { uses monthly time-series data covering 2001: M1 - 2019: M12. } \\
\text { The volatility of stock returns is measured using Generalized } \\
\text { Autoregressive Conditional Heteroskedasticity (GARCH). } \\
\text { By employing the Autoregressive Distributed Lag Model } \\
\text { (ARDL), the results validate the evidence of the long-run } \\
\text { relationship between the stock market's volatility and } \\
\text { macroeconomic variables. A rising in money supply and an } \\
\text { economic upturn reduce the volatility of conventional stock } \\
\text { returns but only an expansionary money supply diminishes } \\
\text { the volatility of Islamic stock returns. Conversely, high } \\
\text { inflation and sharp depreciation of the Rupiah boost the } \\
\text { stock returns' volatility. The results further show an } \\
\text { interesting finding that the Islamic stock market's volatility } \\
\text { is more responsive to changes in macroeconomic indicators } \\
\text { than the volatility of their counterpart conventional stock } \\
\text { market. Policymakers should take strict rules during the } \\
\text { worst economic conditions to minimize the negative impact } \\
\text { of the instability of macroeconomic variables. }\end{array}$ \\
\hline
\end{tabular}

This work is licensed under a Creative Commons Attribution-NonCommercial 4.0 International License.

\section{Introduction}

As the largest Muslim country, Indonesia has two stock market systems, i.e. conventional and Islamic stock markets. The Indonesian capital markets have issued 
Indonesian Stock Exchange (IDX), that trades conventional stocks, and Jakarta Islamic Index (JII), that exchanges the sharia stocks. IDX measures the weighted average of conventional stock prices since 1977. Meanwhile, Indonesia Islamic-based stock index started with the Jakarta Islamic Index (JII) in 2000 (Widarjono et al., 2021). Jakarta Islamic Index provides stock prices in accordance with Islamic values in fulfilling a permitted (halal) portfolio.

The stock market is widely regarded as an important indicator for an economy, either developed or developing countries, because stock markets respond promptly to any economic shocks and any changes in economic policy. The fall in stock prices, therefore, is an early symptom of deteriorating economic conditions, and vice versa. Accordingly, economists and policymakers are interested in exploring the stock market's response to changes in macroeconomic conditions. For instance, a global financial crisis in 2008 has simulated many empirical studies to investigate the sensitivity of stock prices to macroeconomic variables (Ajaz et al., 2017).

Some theories discuss the relation between the stock market's volatility and economic variables, namely Capital Asset Pricing Model (CAPM), Arbitrage Pricing Theory (APT), and Simple Discounted Present Value Model (SDPVM). Based on SDPVM theory, the future cash flows of the company and the discount rate affect the stock prices. The two factors in the SDPVM theory are strongly linked to the volatility of macroeconomic variables and will ultimately influence the stock market's volatility. It means that changes in uncertainty level about future macroeconomic conditions may result in proportional changes in the volatility of stock returns, provided that the discount rate is unchanged (Yusof \& Majid, 2007).

A number of empirical researches have analyzed the sensitivity of conventional stock prices to macroeconomic variables. Ratanapakorn and Sharma (2007), by employing the vector error correction model (VECM) from 1975 to 1999, examined the connection between the US stock price index and some macroeconomic variables. They found that inflation, industrial production index, and exchange rate positively connected to stock prices, but the interest rate was negatively related to the stock prices. In addition, using the Granger Causality test, stocks prices are caused by every macroeconomic variable in the long run. Sim and Zhou (2015) documented that the link between the US stock prices and oil prices is asymmetric. Shocks in negative oil prices influence the stock prices but it is delicate for shocks in positive oil prices.

Chellaswamy et al. (2020), by employing a quantile regression, analyzed the responsiveness of Indian and Chinese stock prices to the interest rate, inflation, and exchange rate with monthly data from 1998:M1 to 2018:M12. The results demonstrated that inflation provided a positive and significant impact on the upper quantiles in Indian Stock prices, while the exchange rate affected Chinese stock prices. More 
specifically, financial economists have paid more attention to the link between exchange rates and stock prices. Bahmani-Oskooee and Saha (2018) explored the asymmetric effect of exchange rates on stock prices from 24 countries using monthly data. The stock prices reacted asymmetrically to the exchange rate where the depreciation had a greater impact than appreciation on stock prices. The asymmetric effect of the exchange rate on stock prices also occurs in Vietnamese stock prices (Dang et al., 2020).

An abundance of empirical studies has investigated the responsiveness of the Islamic stock market to macroeconomic variables. By applying the autoregressive distributed lag model (ARDL), Majid and Yusof (2009) examined the extent to which Islamic stock prices in Malaysia respond to the changes in output, money supply, federal rate, and exchange rate after the financial crisis. Malaysia Islamic stock prices are positively associated with money supply and federal rate but negatively linked to exchange rate. A linkage between Indian Islamic stock prices and macroeconomic variables is found. The wholesale price index (WPI) and money supply possessed positive and significant connection but, as it has been expected, interest rate negatively influenced the Islamic stock returns (Kumar \& Sahu, 2017).

A number of research have also investigated the responsiveness of Indonesia stock prices, both conventional and Islamic stock prices, to macroeconomic indicators. Wahyudi et al. (2017), applying multiple regression with the OLS method, explored the extent to which macroeconomic indicators affected Indonesian stock prices using monthly data from 2007:M1 to 2016:M12. The BI rates and exchange rate negatively influenced the stock prices but money supply as well as the output have no impact on stock prices. Robiyanto et al. (2019), utilizing the GARCH method, documented that the price of world crude oil positively affected the stock prices, but the exchange rate had negative impact on the stock prices for the period of 2005- 2016.

Jakarta Islamic Index, as the representative of the Indonesian Islamic stock market, has a connection to macroeconomic indicators. By employing the VAR model with monthly data covering from 2000 to 2010, Sakti and Harun (2015) found that money supply and inflation positively influenced but the exchange rate negatively affected the Indonesian Islamic stock prices. Widarjono et al. (2021) explored the extent to which the Jakarta Islamic index responds asymmetrically to some macroeconomic conditions, namely money supply, industrial production index, and exchange rate using monthly data from 2000:M1 to 2019:M12. By applying non-linear ARDL (NARDL), Islamic stock prices are asymmetrically affected by the exchange rate and money supply. The appreciation influences the Islamic stock prices. In addition, money supply contraction has a larger effect on Islamic stock prices than a money supply expansion. 
Bridging to this research's issue, the conventional and Islamic stock markets are obviously different. Islamic stock market warrants that firms do not prohibit activities and goods. However, any transaction that leads to highly risky payoffs due to excessive risk-taking behavior (gharar) is prohibited (Siddiqui, 2007; Safiullah \& Shamsuddin, 2019). By contrast, there is no restriction regarding to unlawful goods and any speculative transaction for conventional stock. Therefore, examining the volatility of both Islamic and conventional stock markets becomes an interesting attribute to explore. The previous studies have examined separately the sensitivity of stock prices to macroeconomic variables in Indonesia for conventional stock prices by using OLS (Wahyudi et al., 2017) and GARCH method (Robiyanto et al., 2019) and for Islamic stock prices by using VAR (Sakti \& Harun, 2015) and NARDL method (Widarjono et al., 2021). Hence, studies that compare the behavior of both Islamic and conventional stock markets remain more paucity of evidence.

Drawing on the research gap, the present study aims to explore the effect of macroeconomic variables on the volatility of stock returns both Islamic and conventional. These results of this study contribute the existing empirical studies in some ways. First, this study compares how the volatility of stock returns responds to changes in macroeconomic variables in the Islamic and the conventional stock markets where comprehensive study of both stock markets still remains unexplored according to the best of the authors' knowledge. Second, this study employs the Autoregressive distributed lag (ARDL) method, which can catch the volatility of stock returns on macroeconomic variables in both short-run and long-run conditions.

\section{Hypotheses Development}

The money supply is all the currency and other liquid assets which are used as a means of transaction. The money supply roughly comprises both cash and time deposits. The money supply affects stock prices based on portfolio substitution or inflation effect (Cheung \& Lai, 1999). Referring to the portfolio-balance hypothesis, changes in money supply re-balance stock price according to the quantity theory of money. An expansion in money supply leads to high prices and, in turn, raises the discount rate and lowers stock prices (Fama, 1981). By contrast, a rising in money supply lowers the interest rate and, in turn, increases stock prices (Mukherjee \& Naka, 1995).

Several studies have shown that money supply has a positive effect on stock prices. Money supply has a positive effect on stock prices for conventional stocks (Sakti \& Harun, 2015) and Islamic stock (Widarjono et al., 2021) in Indonesia. Kumar and Sahu (2017) also documented that money supply is positively linked to Islamic stock prices in India. According to the review, a hypothesis is formulated.

H1: The money supply has a negative effect on the volatility of stock market returns. 
Gross domestic product (GDP) represents real economic activity. Due to the unavailability of the monthly data, many empirical studies widely used the industrial production index (IPI). The relation between stock prices and economic activity can be explained as follows. Domestic output upturns positively connect to the profitability of the company through an increase in consumption and investment as a component of GDP expenditure and consequently enhances the stock prices (Chang \& Rajput, 2018). By contrast, a reduction in consumption and investment due to downturn output reduces profitability and lowers stock prices (Wongbangpo \& Sharma, 2002). Accordingly, a rising in output reduces the volatility of stock prices because of a good macroeconomic condition.

Some previous studies indicate that output has a positive effect on stock prices. Pinjaman and Aralas (2015) reveal that the increase in output has a positive effect on sectorial stocks in Malaysia. The increase in output also positively links to conventional stock prices in Pakistan (Chang \& Rajput, 2018). According to the discussion, this study formulates the hypothesis below.

H2: The industrial production index, which represents real output, has a negative effect on the volatility of stock market returns.

Inflation refers to a raising in the general price level. Inflation is generally calculated based on the consumer price index (CPI). In this study, the consumer price index is used to represent the general price level. Inflation negatively affects stock prices through two channels (Fama, 1981). First, inflation reduces output through the quantity theory of money, thereby reducing company profits. Second, inflation raises interest rates and thus increases the discount rate. Finally, an increase in discount rate may lower stock prices. Conversely, a decrease in general price levels or deflation raises firm profits and lowers the discount rate and, in turn, boosts stock prices. High price increases the volatility of stock prices due to a worse economy according to the theory of the Intertemporal Capital Asset Pricing Model (ICAPM) (Merton, 1973).

The existing empirical studies document that inflation negatively links to stock prices. Sakti and Harun (2015), by using VAR, demonstrate that high prices lower conventional stock prices in Indonesia. Other studies also document that inflation has a negative effect on conventional stock prices in India (Kumar \& Sahu, 2017) and China (Chellaswamy et al., 2020). Hence, the following hypothesis is postulated.

H3: The consumer price index, which represents inflation, has a positive effect on the volatility of stock market returns.

The Exchange rate is the price of foreign currency against domestic currency. In this study, the exchange rate used is the US \$ against the Rupiah. The US dollar is used because the US\$ is a strong currency and is widely used for international transactions. 
An indirect relationship between stock prices and exchange rates exists. Exchange rates are directly related to economic activity. The depreciation will increase imported goods and services, further increase the cost of production. The increased price lowers the company's profits and lessens the stock prices. On the other hand, the appreciation will reduce the cost of production and increase profits so that the appreciation will increase the price of stocks (Mukherjee \& Naka, 1995). Accordingly, depreciation increases the volatility of stock prices due to a deteriorated economy.

Several previous studies document that depreciation lowers stock prices while appreciation raises stock prices. Robiyanto et al. (2019) validate that conventional stock prices in Indonesia are negatively related to depreciation. Exchange rates also have a negative effect on stock prices in 24 countries (Bahmani-Oskooee \& Saha, 2018). Dang et al. (2020) also show that depreciation lowers conventional stock prices in Vietnam Thus, a further hypothesis is stated.

H4: The exchange rate has a positive effect on the volatility of stock market returns

\section{Method}

\section{Sample Selection and Data Sources}

This study explores the Indonesian stock returns' volatility, encompassing the Jakarta Islamic Index (JII) and Indonesian Stock Exchange (IDX). The Jakarta Islamic Index (JII) is used to measure the volatility of Islamic stocks, while the Indonesian Stock Exchange (IDX) is employed to measure the volatility of conventional stocks. The monthly data, covering from 2001:M1 to 2019:M12, were taken into account. The selected period is based on information on the availability of Islamic stock data. Islamic stocks were first launched in July 2000, known as the Jakarta Islamic index.

\section{Estimating Model}

This study examines the relationship between volatility of stock returns and macroeconomic variables. It follows some previous research to analyze the sensitivity of stock market returns to macroeconomic variables (Chang \& Rajput, 2018; Chellaswamy et al., 2020; Widarjono et al., 2021). The volatility of stock price returns were expressed using the following regression models:

$$
\begin{aligned}
& V J I I_{t}=\beta_{O}+\beta_{1} L M_{t}+\beta_{2} L I P I_{t}+\beta_{3} L C P I_{t}+\beta_{4} L E X C_{t}+\varepsilon_{t} \\
& V I D X_{t}=\delta_{O}+\delta_{1} L M_{t}++\delta_{2} L I P I_{t}+\delta_{3} L C P I_{t}+\delta_{4} L E X C_{t}+\varepsilon_{t}
\end{aligned}
$$

Where: $V J I I_{t}$ and $V I D X$ are the volatility of Islamic stock return and conventional stock returns, respectively; the independent variables in equations (1) and (2) are macroeconomic variables, including money supply (LM), output (LIPI), inflation (LCPI), and exchange rate (LEXC); the money supply is broad money M2; the output is 
industrial production index; the inflation is the consumer price index; and the exchange rate is the price of Rupiah against to US\$. All Independent variables are expressed in a natural logarithm.

The variance of stock returns is widely applied to measure volatility of stock returns. The Islamic stock returns and conventional stock returns are measured using the following formula as:

$$
\begin{aligned}
& R J I I_{t}=\ln \left[\frac{J I I_{t}}{J I I_{t-1}}\right] \\
& R I D X_{t}=\ln \left[\frac{I D X_{t}}{I D X_{t-1}}\right]
\end{aligned}
$$

Where: JII is Jakarta Islamic index and IDX is Indonesian stock index. This study generates the volatility of stock returns based on the following standard Generalized Autoregressive conditional Heteroskedasticity (GARCH). This study applies GARCH(1,1) (Yusof \& Majid, 2007; Bahmani-Oskooee \& Saha, 2018) as follows:

$$
\begin{aligned}
R_{t} & =\theta_{0}+\theta_{1} R_{t-1}+e_{t} \\
\sigma_{t}^{2} & =\alpha_{0}+\alpha_{i} e_{t-i}^{2}+\lambda_{i} \sigma_{t-i}^{2}
\end{aligned}
$$

Where: $\mathrm{R}$ is the JII returns or the IDX returns and $\sigma_{t}^{2}$ is the conditional variance.

This study applies the Autoregressive Distributed Lag Model (ARDL). Some benefits of employing the ARDL model exist. First, it can be applied to different stationary levels as long as the second differenced stationarity is not found. Second, it can capture the short-run and long-run conditions (Pesaran \& Shin, 1998). The ARDL model for VRJII is as follows:

$$
\begin{aligned}
& \Delta V R J I I_{t}=\alpha_{0}+\alpha_{1} V_{R J I I_{t-1}}+\alpha_{2} L M_{t-1}+\alpha_{3} L I P I_{t-1}+\alpha_{4} L C P I_{t-1}+\alpha_{5} L E X C_{t-1}+ \\
& \sum_{1=1}^{n} \gamma_{1 i} \Delta V R J I I_{t-1}+\sum_{1=1}^{n} \gamma_{2 i} \Delta L M_{t-1}+\sum_{1=1}^{n} \gamma_{3 i} \Delta L I P I_{t-1}+\sum_{1=1}^{n} \gamma_{4 i} \Delta L C P I_{t-1}+ \\
& \sum_{1=1}^{n} \gamma_{5 i} \Delta E X C_{t-1}+\varepsilon_{t}
\end{aligned}
$$

Meanwhile, the ARDL model for VRIDX is as follows:

$$
\begin{aligned}
& \Delta V R I D X_{t}=\sigma_{0}+\sigma_{1} V R I D X_{t-1}+\sigma_{2} L M_{t-1}+\sigma_{3} L I P I_{t-1}+\sigma_{4} L C P I_{t-1}+ \\
& \sigma_{5} L E X C_{t-1}+\sum_{1=1}^{n} \tau_{1 i} \Delta V R I D X_{t-1}+\sum_{1=1}^{n} \tau_{2 i} \Delta L M_{t-1}+\sum_{1=1}^{n} \tau_{3 i} \Delta L I P I_{t-1}+ \\
& \sum_{1=1}^{n} \tau_{4 i} \Delta L C P I_{t-1}+\sum_{1=1}^{n} \tau_{5 i} \Delta L E X C_{t-1}+\varepsilon_{t}
\end{aligned}
$$

Where: $\Delta$ is the first difference variable; $\alpha_{0}$ and $\sigma_{0}$ are constant; $\alpha_{i}$ and $\sigma_{i}$ are the longrun coefficients; $\gamma_{1 i}-\gamma_{5 i}$ and $\tau_{1 i}-\tau_{5 i}$ are the short-run coefficient.

A number of steps are needed to estimate the ARDL model. Initially, this study examines the stationary test using the ADF and PP unit root tests. The next stage is the cointegration test using the bound test approach. The cointegration test is used to determine whether there is a long-term relationship between the dependent variables 
and their explanatory variables. The null hypotheses of no cointegration are $H_{0}=\alpha_{1}=$ $\alpha_{2}=\alpha_{3}=\alpha_{4}=\alpha_{5}=0$ and $H_{0}=\sigma_{1}=\sigma_{2}=\sigma_{3}=\sigma_{4}=\sigma_{5}=0$. If there is cointegration, the ARDL model of equations (7) and (8) can be written in an error correction model as follows:

$$
\begin{aligned}
& \Delta V R J I I_{t}=\gamma_{0}+\sum_{1=1}^{n} \gamma_{1 i} \Delta V R J I I_{t-1}+\sum_{1=1}^{n} \gamma_{2 i} \Delta L M_{t-1}+\sum_{1=1}^{n} \gamma_{3 i} \Delta L I P I_{t-1}+ \\
& \sum_{1=1}^{n} \gamma_{4 i} \Delta L C P I+\sum_{1=1}^{n} \gamma_{5 i} \Delta L E X C_{t-1}+\varphi_{6 i} E C T_{t}+\varepsilon_{t} \\
& \Delta V R I D X_{t}=\emptyset_{0}+\sum_{1=1}^{n} \emptyset_{1 i} \Delta V R I D X_{t-1}+\sum_{1=1}^{n} \emptyset_{2 i} \Delta L M_{t-1}+\sum_{1=1}^{n} \emptyset_{3 i} \Delta L I P I_{t-1}+ \\
& \sum_{1=1}^{n} \emptyset_{4 i} \Delta L C P I_{t-1}+\sum_{1=1}^{n} \emptyset_{5 i} \Delta L E X C_{t-1}+\emptyset_{6 i} E C T_{t}+\varepsilon_{t}
\end{aligned}
$$

This ECM-ARDL model reports the short-run disequilibrium situation since some variables that are not stationary in level but cointegration is found. Therefore, the ECMARDL model contains the lagged error (ECT) to correct the short-run disequilibrium condition in order to warrant the long-run equilibrium. The last step is to estimate the long-run coefficient in the ARDL model.

\section{Results}

Table 1 shows stock returns and stock returns' volatility, both Islamic stock prices and conventional stocks prices. The average of Islamic stock returns is lower than conventional stock returns. In addition, with a lower standard deviation, conventional stock returns are more stable than Islamic stock returns. However, both stock returns are negatively skewed. The standard deviation follows a normal distribution. However, investors consider skewness as the evaluator for the distribution of return since, instead of the average, skewness examines the extremes of the data set. According to the skewness, Islamic stock returns are better than conventional stock returns. The volatility of Islam stock returns is higher than those of conventional stock returns and its standard deviation is also higher than those of conventional stock returns. These findings may imply that the Islamic stock market is a riskier asset than the conventional stock market, confirming the study by Ben Rejeb and Arfaoui (2019).

Table 1. Descriptive Statistics

\begin{tabular}{lcllll}
\hline Variable & Mean & Std. Dev. & Maximum & Minimum & Skewness \\
\hline RJII & 0.0105 & 0.0660 & 0.1981 & -0.3911 & -1.0644 \\
RIDX & 0.0119 & 0.0600 & 0.1834 & -0.3772 & -1.2729 \\
VRJII & 0.0044 & 0.0041 & 0.0254 & 0.0010 & 2.5381 \\
VRIDX & 0.0036 & 0.0030 & 0.0205 & 0.0007 & 2.6149 \\
\hline
\end{tabular}

Figure 1 shows two graphs explaining the stock returns and stock returns' volatility. The left one presents the development of stock returns, both Islamic and 
conventional stock prices from 2001:M1 to 2019:M12. Stock returns were quite volatile at the beginning of the period and reached their peak in 2008 as the world financial crisis started due to the financial crisis in the USA. The stock prices have decreased drastically, causing stock returns to be negative. Stock returns then stabilized after the 2008 world financial crisis. The right one also describes the trend of stock returns' volatility using the GARCH method. This figure supports the development of the stock returns. The volatility was quite high and reached its peak in 2008 because of the world financial crisis. The two graphs show that conventional and Islamic stock prices are closely related. The coefficients of correlation are 0.9608 and 0.9298 for stock returns and stock returns' volatility, respectively, although Islamic stock prices are more volatile. The close relationship between Islamic and conventional stock prices and the existence of asymmetric bidirectional volatility spillovers between the two markets are also found in the Pakistan stock prices (Jebran et al., 2017).
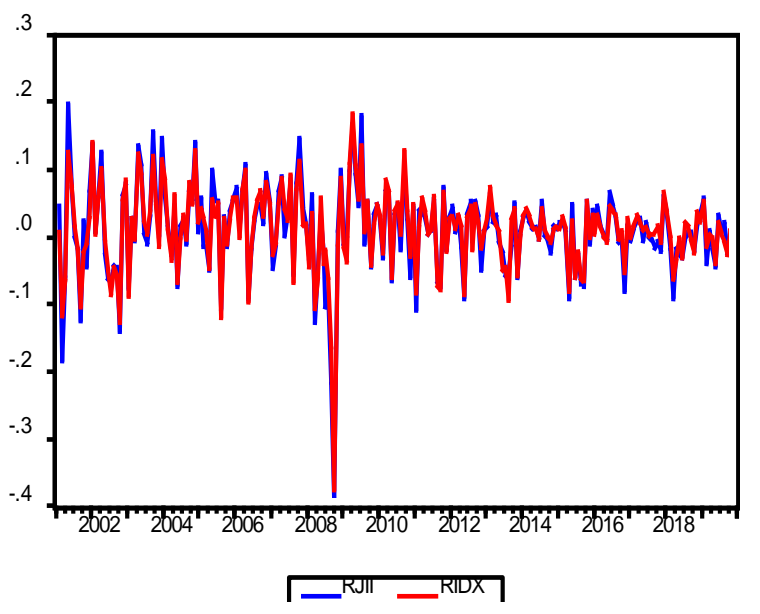

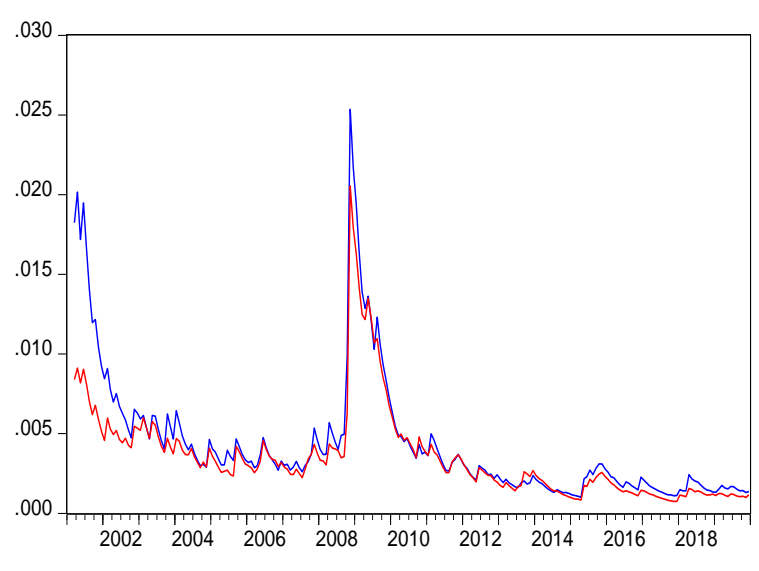

- VRJII — VRIDX

Figure 1. Stock Returns and Stock Returns' Volatility

Before estimating the ARDL model, the authors checks the stationarity of the data using the unit root method of ADF and PP. The results of the ADF and PP tests are presented in Table 2 . The test results report that there are no stationary variables in the second difference data, even though the level of data stationarity is different. The unitroots test results guarantee that the ARDL model is applicable for our estimation.

Table 2. Unit-root Test Results

\begin{tabular}{|c|c|c|c|c|c|c|c|c|}
\hline \multirow[b]{3}{*}{ Variable } & \multicolumn{4}{|c|}{ Level Data } & \multicolumn{4}{|c|}{ Difference Data } \\
\hline & \multicolumn{2}{|c|}{ ADF } & \multicolumn{2}{|c|}{ PP } & \multicolumn{2}{|c|}{ ADF } & \multicolumn{2}{|c|}{ PP } \\
\hline & Constant & Trend & Constant & Trend & Constant & Trend & Constant & Trend \\
\hline VRJII & $-3.713^{* * *}$ & $-4.530^{* *}$ & $*-3.685^{* * *}$ & $-3.807^{* *}$ & $-13.798^{* * *}$ & $-13.838^{* * *}$ & $-13.768^{* * *}$ & $-13.823^{* * *}$ \\
\hline VRIDX & $-3.059^{* *}$ & $-3.400^{*}$ & $-3.024^{* *}$ & $-3.403^{*}$ & $-14.299^{* * *}$ & $-14.273^{* * *}$ & $-14.596^{* * *}$ & $-14.568^{* * *}$ \\
\hline LM & -0.660 & -1.488 & -0.651 & -0.994 & -2.441 & -2.479 & $-17.113^{* * *}$ & $-17.102^{* * *}$ \\
\hline
\end{tabular}




\begin{tabular}{|c|c|c|c|c|c|c|c|c|}
\hline \multirow[b]{3}{*}{ Variable } & \multicolumn{4}{|c|}{ Level Data } & \multicolumn{4}{|c|}{ Difference Data } \\
\hline & \multicolumn{2}{|c|}{ ADF } & \multicolumn{2}{|c|}{ PP } & \multicolumn{2}{|c|}{ ADF } & \multicolumn{2}{|c|}{ PP } \\
\hline & Constant & Trend & Constant & Trend & Constant & Trend & Constant & Trend \\
\hline LIPI & 0.621 & -1.342 & -1.482 & $-9.967^{* * *}$ & $-7.975^{* * *}$ & $-8.000^{* * *}$ & $-52.230^{* * *}$ & $-51.824^{* * *}$ \\
\hline LCPI & $-3.168^{* *}$ & -1.350 & $-3.745^{* * *}$ & -1.217 & $-11.722^{* * *}$ & $-12.294^{* * *}$ & $-11.681^{* * *}$ & $-12.085^{* * *}$ \\
\hline LEXC & -1.110 & -2.684 & -0.831 & -2.252 & $-11.799 * * *$ & $-11.803^{* * *}$ & $-11.466^{* * *}$ & $-11.465^{* * *}$ \\
\hline
\end{tabular}

Note: ${ }^{*}{ }^{* *}$, and ${ }^{* * *}$ report the statistical significant at $10 \%, 5 \%$, and $1 \%$, respectively

After establishing the unit-root test, the authors then estimate the ARDL model by employing the Ordinary Least Squares (OLS) method with the maximum number of 9 lags selected by Akaike Information Criteria (AIC). Table 3 reports ARDL results where the upper part presents the estimation and the lower part indicates the diagnostic test using LM test for autocorrelation test and $\mathrm{ARCH}$ test for heteroskedasticity test. Both VRJII and VRIDX models pass no autocorrelation as well as homoskedasticity. Moreover, Figures 2 and 3 indicate the stability test employing the CUMSUM and CUMSUM of Squares.

Table 3. ARDL results

\begin{tabular}{lllll}
\hline & \multicolumn{3}{c}{ JII } & \multicolumn{2}{c}{ IDX } \\
\cline { 2 - 5 } Variable & Coefficient & Std. Error & Coefficient & Std. Error \\
\hline$C$ & $0.0261^{* *}$ & 0.0110 & 0.0120 & 0.0107 \\
$V R_{t-1}$ & $0.9927^{* * *}$ & 0.0605 & $0.9720^{* * *}$ & 0.0615 \\
$V R_{t-2}$ & $-0.1555^{*}$ & 0.0841 & -0.1368 & 0.0829 \\
$V R_{t-3}$ & -0.0543 & 0.0856 & -0.0962 & 0.0838 \\
$V R_{t-4}$ & 0.0220 & 0.0810 & 0.0394 & 0.0830 \\
$V R_{t-5}$ & $0.1016^{*}$ & 0.0553 & 0.0913 & 0.0831 \\
$V R_{t-6}$ & & & $0.1946^{* *}$ & 0.0816 \\
$V R_{t-7}$ & & & $-0.1577^{* * *}$ & 0.0596 \\
$L M_{t}$ & & 0.0060 & -0.0092 & 0.0056 \\
$L M_{t-1}$ & -0.0025 & 0.0071 & 0.0077 & 0.0066 \\
$L M_{t-2}$ & 0.0018 & 0.0072 & $0.0197^{* * *}$ & 0.0067 \\
$L M_{t-3}$ & $0.0174^{* *}$ & 0.0057 & $-0.0216^{* * *}$ & 0.0065 \\
$L M_{t-4}$ & $-0.0197^{* * *}$ & & 0.0054 & 0.0061 \\
$L M_{t-5}$ & & & 0.0039 & 0.0062 \\
$L M_{t-6}$ & & & -0.0019 & 0.0064 \\
$L M_{t-7}$ & & & -0.0018 & 0.0067 \\
$L M_{t-8}$ & & & $-0.0180^{* * *}$ & 0.0068 \\
$L M_{t-9}$ & & & $0.0141^{* *}$ & 0.0056 \\
$L I P I_{t}$ & & -0.0011 & 0.0014 \\
$L I P I_{t-1}$ & & & 0.0000 & 0.0014 \\
$L I P I_{t-2}$ & & & -0.0016 & 0.0014 \\
$L I P I_{t-3}$ & & 0.0015 & 0.0018 & 0.0014 \\
\hline & -0.0003 & & &
\end{tabular}




\begin{tabular}{lllll}
\hline & \multicolumn{2}{c}{ JII } & \multicolumn{2}{c}{ IDX } \\
\cline { 2 - 5 } Variable & Coefficient & Std. Error & Coefficient & Std. Error \\
\hline$L I P I_{t-4}$ & & & 0.0010 & 0.0014 \\
$L_{P I} I_{t-5}$ & -0.0151 & 0.0113 & $-0.0035^{* * *}$ & 0.0013 \\
$L C P I_{t}$ & 0.0088 & 0.0171 & -0.0087 & 0.0098 \\
$L C P I_{t-1}$ & 0.0111 & 0.0115 & -0.0045 & 0.0145 \\
$L C P I_{t-2}$ & $0.0217^{* * *}$ & 0.0031 & 0.0169 & 0.0102 \\
$L E X C_{t}$ & $-0.0199^{* * *}$ & 0.0032 & $0.0271^{* * *}$ & 0.0031 \\
$L E X C_{t-1}$ & 0.9051 & & $-0.0246^{* * *}$ & 0.0031 \\
$R^{2}$ & 0.2935 & $(0.5880)$ & 0.9174 & \\
$\mathrm{LM}$ & 3.1844 & $(0.0743)$ & 0.5305 & $(0.4664)$ \\
$\mathrm{ARCH}$ & & 0.0116 & $(0.9144)$ \\
\hline
\end{tabular}

Note: ${ }^{*}, * *$, and ${ }^{* * *}$ report the statistical significant at $10 \%, 5 \%$, and $1 \%$, respectively. Parentheses show p-value.
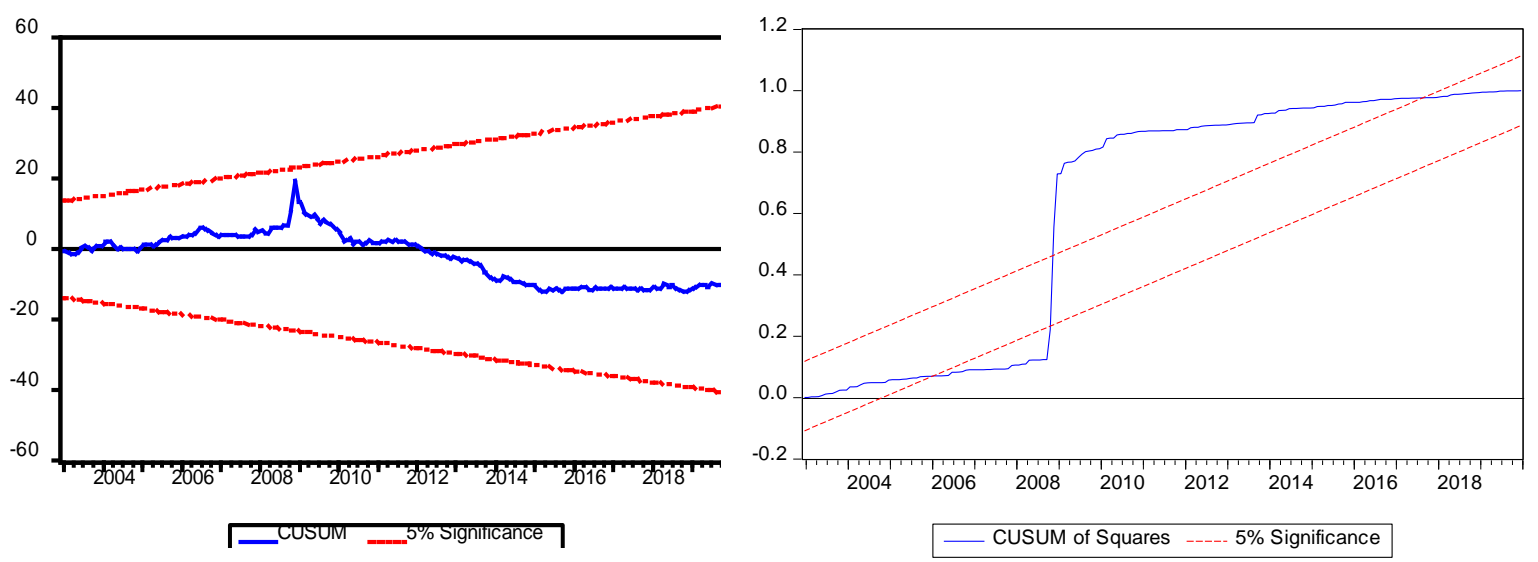

Figure 2. Stability Tests of Islamic Stock Prices

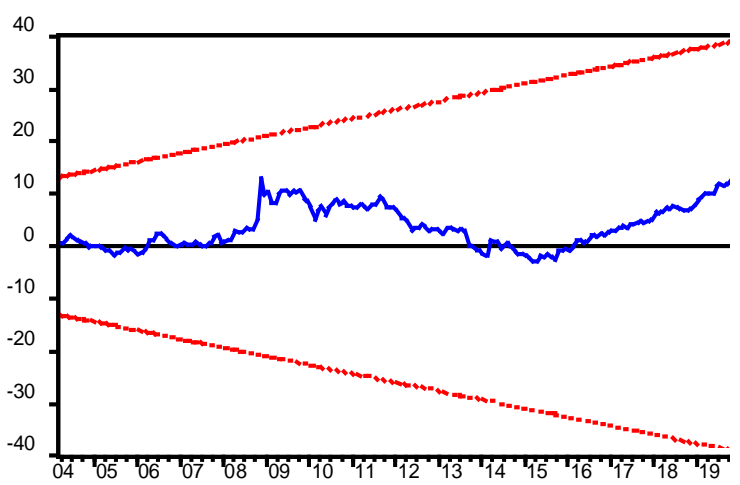

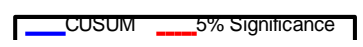

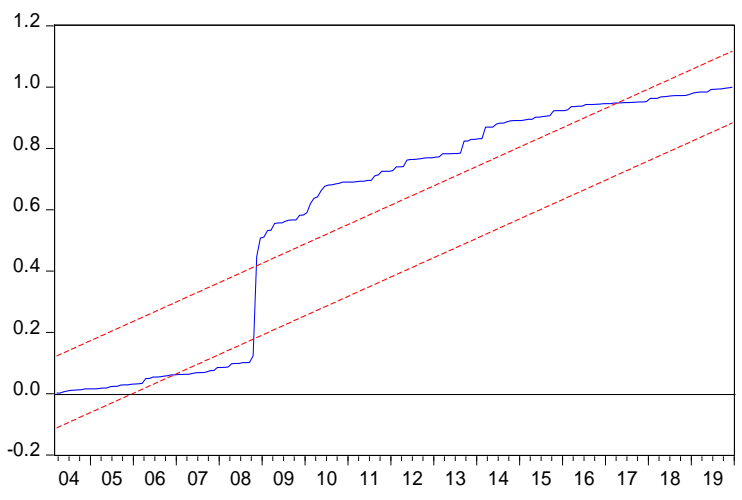

_ CUSUM of Squares ----. $5 \%$ Significance

Figure 3. Stability Tests of Conventional Stock Prices

Having estimated the parameter of ARDL, the authors continue to check the longrun relationship among variables being studied, by employing the cointegration test. The results of the cointegration test are presented in Table 4. The computed F values 
are 3.4360 and 3.1927 for Islamic stock and conventional stock, respectively. The null hypothesis of no cointegration is rejected at $\alpha=10 \%$. These findings conclude that a long-run connection between the volatility of stock returns and all independent variables (Money, IPI, CPI, and exchange rate) are found. Consequently, the ARDL model is applicable to estimate the volatility of stock returns in the short-run and the long-run condition.

Table 4. Result of Cointegration Test

\begin{tabular}{llllll}
\hline & JII & IDX & $\boldsymbol{\alpha}$ & $\begin{array}{l}\text { Lower } \\
\text { bound }\end{array}$ & $\begin{array}{l}\text { Upper } \\
\text { bound }\end{array}$ \\
\hline F-statistic & $3.4360^{*}$ & $3.1927^{*}$ & $1 \%$ & 3.29 & 4.37 \\
$\mathrm{k}$ & 4 & 4 & $5 \%$ & 2.56 & 3.49 \\
& & & $10 \%$ & 2.2 & 3.09 \\
\hline
\end{tabular}

Note: ${ }^{*} * *$, and ${ }^{* * *}$ report the statistical significant at $10 \%, 5 \%$, and $1 \%$, respectively. Lower and upper bounds as the critical F statistics are provided by Pesaran et al. (2001).

After establishing the cointegration, the next step conducted in this study is estimating ECM-ARDL that captures the short-run condition. Table 5 shows the results of the error correction model. Before discussing hypothesis testing in the short run, this paper checks the validity of the ECM model by examining the lagged error variable $\left(E C T_{t-1}\right)$. Based on the result of analysis, the lagged error variable is negative and significant for Islamic stock and conventional stock so that these results guarantee that the error correction model is valid for analyzing short-run conditions.

As depicted in Table 5, the results for Islamic stocks indicate that the stock returns' volatility in the previous period, the money supply, and depreciation have an effect on volatility. The volatility of Islamic stock returns in the previous period has a negative effect on the current volatility while the money supply and depreciation have a positive effect on volatility. The findings of conventional stocks document that the stock returns' volatility in the previous period and all macroeconomic variables have an effect on volatility in the short term. Moreover, the conventional stock returns' volatility in the previous period negatively affects the current volatility. The money supply and inflation negatively affect volatility while the increase in output and depreciation positively influence the volatility. These findings imply that volatility is persistent over time since the lagged of volatility obviously links to the current volatility.

Table 5. ECM-ARDL Results

\begin{tabular}{lllll}
\hline & \multicolumn{2}{c}{ JII } & \multicolumn{2}{c}{ IDX } \\
\cline { 2 - 5 } Variable & Coefficient & Std. Error & Coefficient & Std. Error \\
\hline$\Delta V R_{t-1}$ & 0.0862 & 0.0569 & 0.0655 & 0.0569 \\
$\Delta V R_{t-2}$ & -0.0693 & 0.0575 & -0.0713 & 0.0570 \\
$\Delta V R_{t-3}$ & $-0.1236^{* *}$ & 0.0582 & $-0.1675^{* * *}$ & 0.0574 \\
\hline
\end{tabular}




\begin{tabular}{|c|c|c|c|c|}
\hline \multirow[b]{2}{*}{ Variable } & \multicolumn{2}{|c|}{ JII } & \multicolumn{2}{|c|}{ IDX } \\
\hline & Coefficient & Std. Error & Coefficient & Std. Error \\
\hline$\Delta V R_{t-4}$ & -0.1016 & 0.0549 & $-0.1281^{* *}$ & 0.0564 \\
\hline$\Delta V R_{t-5}$ & & & -0.0368 & 0.0569 \\
\hline$\Delta V R_{t-6}$ & & & $0.1577^{* * *}$ & 0.0564 \\
\hline$\Delta L M_{t}$ & -0.0025 & 0.0051 & $-0.0092^{*}$ & 0.0050 \\
\hline$\Delta L M_{t-1}$ & 0.0023 & 0.0054 & 0.0002 & 0.0050 \\
\hline$\Delta L M_{t-2}$ & $0.0197^{* * *}$ & 0.0054 & $0.0199^{* * *}$ & 0.0049 \\
\hline$\Delta L M_{t-3}$ & & & -0.0018 & 0.0044 \\
\hline$\Delta L M_{t-4}$ & & & 0.0036 & 0.0043 \\
\hline$\Delta L M_{t-5}$ & & & $0.0075^{*}$ & 0.0042 \\
\hline$\Delta L M_{t-6}$ & & & 0.0056 & 0.0047 \\
\hline$\Delta L M_{t-7}$ & & & 0.0038 & 0.0048 \\
\hline$\Delta L M_{t-8}$ & & & $-0.0141^{* * *}$ & 0.0047 \\
\hline$\Delta L I P I_{t}$ & & & -0.0011 & 0.0013 \\
\hline$\Delta L I P I_{t-1}$ & & & 0.0024 & 0.0015 \\
\hline$\Delta L I P I_{t-2}$ & & & 0.0008 & 0.0015 \\
\hline$\Delta L I P I_{t-3}$ & & & $0.0025^{*}$ & 0.0015 \\
\hline$\Delta L I P I_{t-4}$ & & & $0.0035^{* * *}$ & 0.0012 \\
\hline$\Delta L C P I_{t}$ & -0.0151 & 0.0111 & -0.0087 & 0.0091 \\
\hline$\Delta L C P I_{t-1}$ & -0.0111 & 0.0106 & $-0.0169^{*}$ & 0.0098 \\
\hline$\Delta L E X C_{t}$ & $0.0217^{* * *}$ & 0.0030 & $0.0271^{* * *}$ & 0.0030 \\
\hline$E C T_{t-1}$ & $-0.0935^{* * *}$ & 0.0203 & $-0.0935^{* * *}$ & 0.0211 \\
\hline $\mathrm{R}$ & 0.3388 & & 0.4549 & \\
\hline
\end{tabular}

Note: ${ }^{*}, * *$, and ${ }^{* * *}$ report the statistical significant at $10 \%, 5 \%$, and $1 \%$, respectively.

Furthermore, the next analysis is the long-run condition. The long-run coefficients are shown in Table 6. As presented in Table 6, the coefficient of the money supply is negative and significant, whereas the coefficients of inflation and exchange rate are positive and significant for the Islamic stock market. These results are in accordance with the hypotheses developed previously, in which the money supply has a negative effect on the volatility of stock market returns. The output is negative and insignificant. This result indicates that an increase in the money supply diminishes the volatility of Islamic stock returns. In contrast, high inflation and depreciation of the Rupiah magnify the Islamic stock returns' volatility. The coefficients of money supply and output are negative and significant while the coefficients of inflation and output are positive and significant as previously hypothesized for the conventional stock market. This evidence implies that the money supply expansion and output upturn will reduce the volatility of conventional stock returns. Conversely, the high inflation and the depreciation of the Rupiah will boost the volatility of conventional stock returns.

This result proved that macroeconomic indicators apparently connect to the stock prices and their volatility. Because stock prices are related to cash flows and the 
discount rate, the stock markets respond quickly to change in macroeconomic condition shocks according to the theory of discounted present value. This study supports the previous studies related to the Islamic stock market (Habib \& Islam, 2017; Kumar \& Sahu, 2017; Widarjono et al., 2021) and conventional stock market (Chang \& Rajput, 2018; Dang et al., 2020; Chellaswamy et al., 2020).

Table 6. Long Run ARDL Results: AIC Method

\begin{tabular}{lllll}
\hline \multirow{2}{*}{ Variable } & \multicolumn{2}{c}{ JII } & \multicolumn{2}{c}{ IDX } \\
\cline { 2 - 5 } & Coefficient & Std. Error & Coefficient & Std. Error \\
\hline$C$ & $0.2788^{*}$ & 0.1469 & 0.1282 & 0.1186 \\
$L M_{t}$ & $-0.0314^{* *}$ & 0.0147 & $-0.0176^{*}$ & 0.0120 \\
$L I P I_{t}$ & -0.0034 & 0.0153 & $-0.0379^{*}$ & 0.0214 \\
$L C P I_{t}$ & $0.0513^{* *}$ & 0.0243 & $0.0394^{* *}$ & 0.0197 \\
$L E X C_{t}$ & $0.0197^{* *}$ & 0.0091 & $0.0270^{* *}$ & 0.0109 \\
\hline
\end{tabular}

Note: ${ }^{*}, * *$, and ${ }^{* * *}$ report the statistical significant at $10 \%, 5 \%$, and $1 \%$, respectively.

As for the distributed lag model, the results of the ARDL model depend on the selected optimum lag. In addition to the AIC method, there are several methods for selecting the optimum lag, i.e. Schwarz criterion (SC), Hannan-Quinn criterion (HQ), adjusted $R^{2}$ method. This study also estimates the ARDL model using adjusted $R^{2}$ and SC methods to warrant the robustness of the AIC results. The findings are reported in Table 7. Except for output, all macroeconomic variables are significant and according to the expected hypothesis. Good macroeconomic conditions support stock prices and reduce volatility while worse macroeconomic conditions boost volatility.

Table 7. Long Run ARDL Results: SC and Adjusted $R^{2}$ Method

\begin{tabular}{lllll}
\hline \multirow{2}{*}{ Variable } & \multicolumn{2}{c}{ JII } & \multicolumn{2}{c}{ IDX } \\
\cline { 2 - 5 }$C$ & SC & Adjusted $\boldsymbol{R}^{\mathbf{2}}$ & SC & Adjusted $\boldsymbol{R}^{\mathbf{2}}$ \\
\hline \multirow{2}{*}{$L M_{t}$} & $0.3289^{*}$ & 0.2385 & 0.1726 & 0.1548 \\
& $(0.1770)$ & $(0.1633)$ & $(0.1092)$ & $(0.1357)$ \\
${ }_{L I P I_{t}}$ & $-0.0348^{* *}$ & $-0.0318^{* *}$ & $-0.0197^{* *}$ & $-0.0206^{*}$ \\
& $(0.0176)$ & $(0.0165)$ & $(0.0111)$ & $(0.0140)$ \\
$L_{C P I_{t}}$ & -0.0033 & -0.0045 & -0.0109 & -0.0309 \\
& $(0.0167)$ & $(0.0263)$ & $(0.0132)$ & $(0.0245)$ \\
$L E X C_{t}$ & $0.0605^{* *}$ & $0.0498^{* *}$ & $0.0341^{* *}$ & $0.0414^{* *}$ \\
& $(0.0298)$ & $(0.0240)$ & $(0.0178)$ & $(0.0218)$ \\
& $0.0175^{* *}$ & $0.0259^{* * *}$ & $0.0161^{* *}$ & $0.0266^{* *}$ \\
\hline
\end{tabular}

Note: ${ }^{* *}{ }^{* *}$, and ${ }^{* * *}$ report the statistical significant at $10 \%, 5 \%$, and $1 \%$, respectively. The parentheses report the standard errors. 


\section{Discussion}

The depreciation of the Rupiah increases the volatility of Islamic and conventional stock returns both in the short-run and the long-run condition. Meanwhile, other variables do not match the expected hypothesis in the short run because the short-run condition is a disequilibrium condition. By contrast, the economic theory represents a long-run equilibrium condition after every economic agent adjusts the disequilibrium condition in the short run. The empirical findings imply that exchange rate pass-through stock prices exist both in the short run and the long run (Bahmani-Oskooee \& Saha, 2018; Chang \& Rajput, 2018).

According to the long-run coefficient, this study indicates that stable economic conditions during a positive growth of money supply reduce the volatility of Islamic and conventional stock returns. This finding shows that the first hypothesis is accepted. A rise in money supply enhances a company's cash flow, thus boosting the stock price and reducing the volatility (Mukherjee \& Naka, 1995). This study's results are lined with the existing studies where increasing in money supply reduce the stock return's volatility in Malaysia Islamic stock market (Yusof \& Majid, 2007), the conventional stock market in some developed and emerging markets (Bahloul et al, 2017), and Pakistan stock market (Ilyas et al., 2021).

The volatility of conventional stock returns also depends on the output. Stable economic conditions with an increase in output reduce volatility. This finding proves the second hypothesis. An increase in output leads to a rising in income and consumption so that company generates high profit, which in turn will increase stock prices and reduce volatility (Abduh \& Surur, 2013). Our findings confirm the previous studies such as Yusof and Majid (2007) in the context of Malaysian Islamic and conventional stock markets and in the context of China and the US stock market (Jin \& Guo, 2021).

A deteriorating economic condition with high inflation raises volatility. This finding is in accordance with the third hypothesis. According to the classical theory of money, inflation lower firm profits through a higher interest rate then it increases the volatility of stock returns (Pinjaman \& Aralas (2015). This study supports the existing empirical literature such as Dang et al. (2020) in the context of the Vietnam stock market and Naseer et al. (2021) in the Pakistan stock market.

The depreciation of the domestic currency raises volatility. This finding is in accordance with the fourth hypothesis. Indonesia relies upon imported raw materials for domestic production, so the depreciation boosts inflation and deteriorates macroeconomic condition and the worst macroeconomic condition further enhances volatility (Sivarethinamohan et al., 2021). These results support the previous study that depreciation depresses Islamic stock prices' volatility (Widarjono et al., 2021). Other 
studies also document that depreciation increases the volatility through a decrease in stock prices in the Indonesian stock prices (Endri et al., 2020; Nugroho \& Robiyanto, 2021) and in the Vietnam stock prices (Dang et al., 2020).

The volatility of Islamic and conventional stock returns depends on macroeconomic conditions. Economic upturn with an increase in the money supply and output reduces volatility but an economic downturn with high inflation and sharp depreciation enhances volatility. More interestingly, the Islamic stock market is more responsive to changes in macroeconomic indicators than the conventional stock market because the Islamic stock market shows a greater degree of risk than the conventional stock market due to higher volatility (Dewandaru et al., 2015). This finding confirms the study by Ben Rejeb and Arfaoui (2019), who find that the Islamic stock market is a high risk asset so the Islamic stock market is sensitive to change in macroeconomic variables.

\section{Conclusion}

The in-hand study aims to explore the extent to which the industrial production index, broad money supply, consumer price index, and exchange rate as the macroeconomic indicators affect the volatility of Islamic and conventional stock returns. The volatility of stocks returns is measured using the GARCH method. This paper applies the ARDL method using the monthly data. The Islamic stock returns are more volatile than their counterpart conventional stock returns. This study reveals that worse economic conditions through high inflation and sharp depreciation of Rupiah against US \$ apparently increase the volatility of both stock returns. Conversely, the good economic condition clearly lessens the volatility of both stock returns through an increase in money supply and domestic output. The result obviously supports the theory of discounted present value. Moreover, the Islamic stock market is more responsive to changes in macroeconomic indicators than the conventional stock market.

These results have some policy implications. First, the evidence of the high risk of the Islamic stock market implies that policy makers should make strict rules to minimize the negative impact due to the instability of macroeconomic variables during economic downturns. Second, inflation is the dominant factor in influencing the volatility of stock returns, so the inflation with a low target is important to support the Indonesian stock market. The Indonesian economy is an open economy instead of a closed economy. However, this study focuses only on domestic variables that affect the volatility of Indonesian stock markets both Islamic and conventional stock market. Therefore, future research should include international variables to capture the impact of foreign factors on the volatility of stock returns. 


\section{Authors' Declaration}

The authors made substantial contributions to the conception and design of the study. The authors took responsibility for data analysis, interpretation and discussion of results. The authors read and approved the final manuscript.

\section{ORCID}

Septiana Indarwati (D) https://orcid.org/0000-0002-6715-4608

Agus Widarjono (D) https://orcid.org/0000-0002-1027-5337

\section{References}

Abduh, M., \& Surur, M. (2013). The Dynamics of Macroeconomics Variables and The Volatility of Indonesia Stock Markets : Evidence from Islamic and Conventional Stock Markets. Journal of Islamic Banking and Finance, 30(2), 25-33. Ajaz, T., Nain, M. Z., Kamaiah, B., \& Sharma, N. K. (2017). Stock prices, exchange rate and interest rate: evidence beyond symmetry. Journal of Financial Economic Policy, 9(1), 2-19. https://doi.org/10.1108/JFEP-01-2016-0007

Bahloul, S., Mroua, M., \& Naifar, N. (2017). The impact of macroeconomic and conventional stock market variables on Islamic index returns under regime switching. Borsa Istanbul Review, 17(1), 62-74.

https://doi.org/10.1016/j.bir.2016.09.003

Bahmani-Oskooee, M., \& Saha, S. (2018). On the relation between exchange rates and stock prices: a non-linear ARDL approach and asymmetry analysis. Journal of Economics and Finance, 42(1), 112-137. https://doi.org/10.1007/s12197-017-9388-8

Ben Rejeb, A., \& Arfaoui, M. (2019). Do Islamic stock indexes outperform conventional stock indexes? A state space modeling approach. European Journal of Management and Business Economics, 28(3), 301-322. https://doi.org/10.1108/EJMBE-08-2018-0088

Chang, B. H., \& Rajput, S. K. O. (2018). Do the changes in macroeconomic variables have a symmetric or asymmetric effect on stock prices? Evidence from Pakistan. South Asian Journal of Business Studies, 7(3), 312-331. https://doi.org/10.1108/SAJBS-07-2018-0077

Chellaswamy, K. P., Natchimuthu, N., \& Faniband, M. (2020). Stock market sensitivity to macroeconomic factors: Evidence from China and India. Asian Economic and Financial Review, 10(2), 146-159.

https://doi.org/10.18488/journal.aefr.2020.102.146.159

Cheung, Y. W., \& Lai, K. S. (1999). Macroeconomic determinants of long-term stock market comovements among major EMS countries. Applied Financial Economics, 9(1), 73-85. https://doi.org/10.1080/096031099332546 
Dang, V. C., Le, T. L., Nguyen, Q. K., \& Tran, D. Q. (2020). Linkage Between Exchange Rate and Stock Prices: Evidence from Vietnam. The Journal of Asian Finance, Economics and Business, 7(12), 95-107. https://doi.org/10.13106/jafeb.2020.vol7.no12.095

Dewandaru, G., Bacha, O. I., Masih, A. M. M., \& Masih, R. (2015). Risk-return characteristics of Islamic equity indices: Multi-timescales analysis. Journal of Multinational Financial Management, 29, 115-138. https://doi.org/10.1016/j.mulfin.2014.11.006

Endri, E., Abidin, Z., Simanjuntak, T. P., \& Nurhayati, I. (2020). Indonesian stock market volatility: GARCH model. Montenegrin Journal of Economics, 16(2), 7-17. https://doi.org/10.14254/1800-5845/2020.16-2.1

Fama, E. F. (1981). Stock Returns , Real Activity , Inflation, and Money. The American Economic Review, 71(4), 545-565.

Habib, M., \& Islam, K. U. (2017). Impact of Macroeconomic Variables on Islamic Stock Market Returns : Evidence From Nifty 50 Shariah Index. Journal of Commerce $\mathcal{E}$ Accounting Research, 6(1), (37-44).

Ilyas, U., Butt, M. U., \& Gulzar, M. (2021). Exploring Philosophy of Co-Movements Between Stocks and Macroeconomic Variables. Etikonomi, 20(1), 67-76. https://doi.org/10.15408/etk.v20i1.17614

Jebran, K., Chen, S., \& Tauni, M. Z. (2017). Islamic and conventional equity index comovement and volatility transmission: Evidence from Pakistan. Future Business Journal, 3(2), 98-106. https://doi.org/10.1016/j.fbj.2017.05.001

Jin, Z., \& Guo, K. (2021). The Dynamic Relationship between Stock Market and Macroeconomy at Sectoral Level: Evidence from Chinese and US Stock Market. Complexity, 2021. https://doi.org/10.1155/2021/6645570

Kumar, K. K., \& Sahu, B. (2017). Dynamic Linkages Between Macroeconomic Factors and Islamic Stock Indices in a Non-Islamic Country India. The Journal of Developing Areas, 51(1), 193-205. https://doi.org/10.1353/jda.2017.0011

Majid, M. S. A., \& Yusof, R. M. (2009). Long-run relationship between Islamic stock returns and macroeconomic variables: An application of the autoregressive distributed lag model. Humanomics, 25(2), 127-141. https://doi.org/10.1108/08288660910964193

Merton, R. C. (1973). An Intertemporal Capital Asset Pricing Model. Econometrica, 41(5), 867-887.

Mukherjee, T. K., \& Naka, A. (1995). Dynamic Relations Between Macroeconomic Variables and the Japanese Stock Market: an Application of a Vector Error Correction Model. Journal of Financial Research, 18(2), 223-237. https://doi.org/10.1111/j.1475-6803.1995.tb00563.x 
Naseer, M. M., Khan, M. A., Popp, J., \& Oláh, J. (2021). Firm, Industry and Macroeconomics Dynamics of Stock Returns: A Case of Pakistan Non-Financial Sector. Journal of Risk and Financial Management, 14(5), 190.

https://doi.org/10.3390/jrfm14050190

Nugroho, A. D., \& Robiyanto, R. (2021). Determinant of Indonesian Stock Market's Volatility During the Covid-19 Pandemic. Jurnal Keuangan Dan Perbankan, 25(1), 1-20. https://doi.org/10.26905/jkdp.v25i1.4980

Pesaran, M. H., \& Shin, Y. (1998). An Autoregressive Distributed-Lag Modelling Approach to Cointegration Analysis. Econometrics and Economic Theory in the 20th Century: The Ragnar Frisch Centennial Symposium.

https://doi.org/10.1017/ccol0521633230.011

Pesaran, M. Hashem, Shin, Y., \& Smith, R. J. (2001). Bounds testing approaches to the analysis of level relationships. Journal of Applied Econometrics, 16(3), 289-326. https://doi.org/10.1002/jae.616

Pinjaman, S. B, \& Aralas, S. B. (2015). The Dynamic Stock Returns Volatility and Macroeconomic Factors in Malaysia: A Sectoral Study. South East Asia Journal of Contemporary Business, Economics and Law, 8(3), 33-40.

Ratanapakorn, O., \& Sharma, S. C. (2007). Dynamic analysis between the US stock returns and the macroeconomic variables. Applied Financial Economics, 17(5), 369-377. https://doi.org/10.1080/09603100600638944

Robiyanto, R., Santoso, M. A., Atahau, A. D. R., \& Harijono, H. (2019). The Indonesia stock exchange and its dynamics: An analysis of the effect of macroeconomic variables. Montenegrin Journal of Economics, 15(4), 59-73.

https://doi.org/10.14254/1800-5845/2019.15-4.5

Safiullah, M., \& Shamsuddin, A. (2019). Asset pricing factors in Islamic equity returns. International Review of Finance, 21(2), 1-32. https://doi.org/10.1111/irfi.12290

Sakti, M. R. P., \& Harun, M. Y. (2015). Relationship between Islamic Stock Prices and Macroeconomic Variables: Evidence from Jakarta Stock Exchange Islamic Index. Global Review of Islamic Economics and Business, 1(1), 071. https://doi.org/10.14421/grieb.2013.011-06

Siddiqui, R. (2007). Shari 'ah Compliance, Performance, and Conversion: The Case of the Dow Jones Islamic Market Index ${ }^{\mathrm{SM}}$. Chicago Journal of International Law, 7(2), 495-519.

Sim, N., \& Zhou, H. (2015). Oil prices, US stock return, and the dependence between their quantiles. Journal of Banking and Finance, 55, 1-8. https://doi.org/10.1016/j.jbankfin.2015.01.013

Sivarethinamohan, R., Asaad, Z. A., Mohamed, B., Marane, R., \& Sujatha, S. (2021). Envisaging Macroeconomics Antecedent Effect on Stock Market Return in 
India. Journal of Asian Finance, Economics and Business, 8(8), 311-324.

https://doi.org/10.13106/jafeb.2021.vol8.no8.0311

Wahyudi, R. N., Asdar, M., \& Nohong, M. (2017). The Influence of Macroeconomic Variables Toward Jakarta Composite Index on Indonesia Stock Exchange. JBMI (Jurnal Bisnis, Manajemen, Dan Informatika), 14(2), 131-148.

https://doi.org/10.26487/jbmi.v14i2.2164

Widarjono, A., Shidiqie, J. S. A., \& El Hasanah, L. L. N. (2021). The Sensitivity of the Indonesian Islamic Stock Prices to Macroeconomic Variables : An Asymmetric Approach. Journal of Asian Finance, Economics and Business, 8(3), 181-190. https://doi.org/10.13106/jafeb.2021.vol8.no3.0181

Wongbangpo, P., \& Sharma, S. C. (2002). Stock market and macroeconomic fundamental dynamic interactions: ASEAN-5 countries. Journal of Asian Economics, 13(1), 27-51. https://doi.org/10.1016/S1049-0078(01)00111-7

Yusof, R., \& Majid, M. (2007). Stock Market Volatility Transmission in Malaysia: Islamic Versus Conventional Stock Market. Journal of King Abdulaziz UniversityIslamic Economics, 20(2), 19-40. https://doi.org/10.4197/islec.20-2.2 